\title{
Influenciadoras digitais e seu papel no mercado de Vitória da Conquista, Bahia
}

\author{
Julie Anne Costa Santos de Lima \\ Almiralva Ferraz Gomes ${ }^{2}$ \\ Marcelo Santos Amaraß
}

\begin{abstract}
Resumo: Nos dias atuais, com o poder das redes sociais, surge uma atividade empreendedora em que pessoas são capazes de formar opinião e auxiliar organizações, tanto na captação de clientes quanto no respeito aos seus desejos e necessidades. Embora recente, a atividade desempenhada por influenciadores digitais ganha expressividade no mercado conquistense. O objetivo do presente trabalho é, portanto, analisar o papel de influenciadores digitais em Vitória da Conquista, Bahia. A metodologia utilizada neste estudo é descritivoexploratória e de natureza teórico-empírica. $\mathrm{O}$ instrumento de coleta de dados foi um questionário aplicado entre dezesseis blogueiras. Adotando o critério de acessibilidade, realizaram-se entrevistas com roteiro semiestruturado com cinco influenciadoras. Os dados receberam tratamento quali-quantitativo. Conforme evidenciam os resultados, as formadoras de opinião viabilizam um melhor relacionamento da organização com o seu públicoalvo, além de facilitar a coleta de informações sobre os desejos e necessidades do potencial consumidor. Ademais, segundo as entrevistas e a apuração dos dados, as empresas aumentam a sua receita e ganham maior visibilidade.
\end{abstract}

Palavras-chave: Empreendedorismo. Influenciadoras digitais. Redes sociais.

\section{Introdução}

Nunca se falou tanto da importância de ideias inovadoras para influenciar o consumidor na hora da decisão de comprar. A novidade, no entanto, consiste em formar pessoas capazes de assegurar esse feito sem altos custos, inclusive porque a inovação relaciona-se intimamente a ganhos de vantagem competitiva e a um mercado em que o consumidor é cada vez mais exigente.

Analisar como ocorrem a exploração da imagem de pessoas públicas e o poder de persuasão é uma fonte de vantagem competitiva para as organizações. Explorar a imagem de formadores de opinião não é algo novo, a publicidade e a propaganda já se valem dessa ideia há muito tempo. No caso das redes sociais, entretanto, uma relação mais estreita entre determinada personalidade e o público-alvo faz com que o consumidor acredite na qualidade do produto ou do serviço divulgado. Investigar de que forma as mídias sociais, por meio das formadoras de opinião, constituem uma estratégia de diferenciação das empresas, tornou-se, portanto, uma oportunidade de pesquisa.

\footnotetext{
${ }^{1}$ Graduada em Administração pela Universidade Estadual do Sudoeste da Bahia (UESB) juliecostasantos@gmail.com

2 Professora Titular da Universidade Estadual do Sudoeste da Bahia (UESB) e Doutora em Administração pela Universidade Federal de Lavras (UFLA) almiralva@gmail.com

${ }^{3}$ Professor Adjunto da Universidade Estadual do Sudoeste da Bahia (UESB) e Doutor em Administração pela Universidade Federal da Bahia (UFBA) amaral69@gmail.com
}

Página 210 Caderno de Ciências Sociais Aplicadas, Vitória da Conquista/BA, vol. 14, n 24, ano 14, p. 210-229, jul/dez 2017. 
O presente estudo visa analisar o papel das influenciadoras digitais no mercado de Vitória da Conquista. Com o intuito de facilitar o entendimento sobre o assunto, organizou-se o artigo da seguinte forma: além desta introdução, fez-se um breve debate teórico sobre empreendedorismo e inovação, trazendo à discussão os temas ação empreendedora versus ação gerencial e redes sociais como meio de comunicação. Após a apresentação dos procedimentos metodológicos, passou-se à análise dos dados empíricos e, por fim, às considerações finais.

\section{Empreendedorismo e inovação}

Na concepção de Schumpeter (1985), empreendedor é aquele que possui a capacidade de modificar e contribuir para a melhoria do sistema econômico e social, pois, mediante propostas e criações, o novo aparece, gerando riqueza, produtos e oportunidades de trabalho. Sobre isso, Filion (1999, p.19) verifica que “[...] um empreendedor é uma pessoa que imagina, desenvolve e realiza visões".

Definir empreendedorismo, admitindo que o tema é fruto de um processo que depende de transformações e inovações, não é fácil. Lenzi (2009, p. 8), no entanto, conceitua: “[...] empreendedorismo é o fenômeno de desenvolvimento econômico, social e comportamental que move os empreendedores no sentido de mudar situações comuns atuais com a visão voltada para o futuro”.

Desse modo, o entendimento é de que o empreendedor gera mudanças, econômica e social, de comportamento. Para Julien (2010, p. 17), “[...] qualquer criação ou desenvolvimento de empresa tem impacto não apenas sobre ela mesma, mas também sobre o mercado local e possivelmente nacional ou internacional, o que acaba por provocar mudanças no tecido industrial territorial”. Logo, o empreendedor inova, assume riscos e transforma o meio social. Em função disso, pode haver distinções entre ação empreendedora e ação gerencial.

Perceber tais diversidades permite identificar características singulares da ação empreendedora, mais adaptáveis à realidade do cenário econômico mundial. As diferenças entre as duas atividades concentram-se na maneira de entender o funcionamento do mercado e de se posicionar, quando se consideram as mudanças em um contexto de grandes incertezas. Julien (2010, p. 24) garante que

O empreendedor está no coração da criação e do desenvolvimento de uma empresa. Ele é de fato um indivíduo um pouco particular, seja no mercado capitalista ou em outro. Mas é também um ser social que deve considerar as possibilidades e os limites da sociedade em que vive.

Página 211 Caderno de Ciências Sociais Aplicadas, Vitória da Conquista/BA, vol. 14, n 24, ano 14, p. 210-229, jul/dez 2017. 
O empreendedor observa o ambiente em que vive e adapta seu negócio às possíveis oportunidades ou ameaças. De acordo com Lenzi (2009), empreendedor não é aquele que está refém da própria sorte, mas aquele que planeja a abertura de um negócio e reúne habilidades gerenciais para administrar conscientemente os recursos. Tais fatores se transformam em ações e resultados e, dessa forma, geram resultados satisfatórios. Lenzi (2009) revela que o conhecimento é representado pelo nível de informação que se tem em relação ao negócio (empresa ou carreira) e pelo nível gerencial do empreendedor.

Julien (2010) refere-se a quatro grandes tipos de empreendedor: empreendedor de reprodução, que muda muito pouco o ambiente e, consequentemente, cria menos valor; o empreendedor de imitação, que também não cria muito valor, mas é fortemente influenciado pela criação existente; o empreendedor de valorização, que se destaca ao desenvolver rotinas de gestão e garante a fidelidade de seu público-alvo, além de promover mudanças importantes com estratégias ativas; e o empreendedor de aventura, que se destaca pelo uso da inovação e pela administração dos riscos.

Empreender, no entanto, difere de gerenciar. De acordo com Filion (1999), enquanto os empreendedores definem sua estrutura de trabalho, os gerentes tendem a se adaptar a estruturas previamente estabelecidas, com base na cultura organizacional das empresas, e atuam com o mínimo de surpresas e incertezas. Assim, empreender é criar ações que resultam em mudanças no meio em que a empresa se insere. Gerenciar é adaptar-se às modificações advindas do meio externo.

O empreendedorismo tem estreita relação com a inovação, embora seja necessário cautela para não criar estereótipos quanto à imagem do empreendedor. Drucker (2008, p. 39) ressalta que “A inovação é o instrumento específico do espírito empreendedor. É o ato que contempla os recursos com a nova capacidade de criar riqueza. A inovação, de fato, cria um recurso".

O interesse do empreendedor vai além da obtenção de riquezas ou de lucro por meio do negócio. A motivação passa necessariamente pelo prazer de criar, de desenvolver aquilo que proporciona benefício às pessoas. As estratégias que resultam em desenvolvimento quase sempre vêm acompanhadas de riscos e tal fator deve ser considerado. Shumpeter (1985) afirma que, apesar de arriscada, a inovação, quando bem estabelecida, gera lucro. De acordo com o autor, apenas "alguns" têm a qualidade de saber utilizar a inovação. Portanto, a visão shumpeteriana relaciona a inovação ao desbravamento de mercados.

Página 212 Caderno de Ciências Sociais Aplicadas, Vitória da Conquista/BA, vol. 14, n 24, ano 14, p. 210-229, jul/dez 2017. 


\section{Redes sociais como meio de comunicação e consumo}

A necessidade do ser humano de se comunicar é vital. Além disso, o homem também busca novas formas de expandir seus relacionamentos, de modo a alcançar maiores níveis de interação com pessoas e grupos. Nesse cenário, surgem as redes sociais, que reúnem, em um ambiente, formas de comunicação e de troca de informações. Tomáel, Alcará e Di Chiara (2005) afirmam que o ser humano se agrupa e estabelece relações de interesses que se modificam com o tempo.

O agrupamento de pessoas associa-se a fatores, como interesses, estilos, modos de viver, entre outros, e também ocorre no campo virtual. Ainda de acordo com Tomáel, Alcará e Di Chiara (2005, p. 93), “[...] a inserção em rede é determinante para o compartilhamento da informação e do conhecimento" e isso se deve ao fato de que as redes são espaços que recebem valor no compartilhamento da informação e construção do conhecimento (TOMÁEL, ALCARÁ e DI CHIARA, 2005).

Segundo Almeri e colaboradores (2013), o objetivo das redes sociais é formar grupos de interação social para compartilhar informações. Desse modo, as organizações valem-se do grande número de pessoas que utilizam essa plataforma de comunicação para expor produtos, marcas ou ideias. Contudo, mais do que realizar negócios, as redes sociais diminuem a distância entre empresas, clientes, fornecedores, concorrentes e comunidade.

Almeida e colaboradores (2016) consideram que o grande desafio e o objetivo do marketing é entender o comportamento do consumidor. Acreditam também que as redes sociais têm um grande poder de divulgação de produtos e serviços - quase sempre com custos mais baixos, se comparados aos apresentados em outros canais de comunicação. Por conseguinte, não é mais possível planejar uma linha de produção sem antes conhecer a preferência do mercado.

Com isso, o meio digital passa a ser um recurso eficiente. À medida que a informação se torna mais valiosa para as empresas, saber lidar com ela, adequando-se à velocidade com que é transmitida, por exemplo, passa a ser uma condição para atingir os objetivos. Tomáel, Alcará e Dichiara (2005, p. 94) estabelecem: “[...] a partir do desenvolvimento dos meios de comunicação, principalmente depois da internet, as relações sociais prescindem ao espaço físico e do geográfico, elas ocorrem independentes do tempo e/ou do espaço". Logo, o fenômeno da tecnologia da informação influencia o comportamento humano, uma vez que está relacionado à geração de conhecimento e ao acesso a novas informações.

Página 213 Caderno de Ciências Sociais Aplicadas, Vitória da Conquista/BA, vol. 14, n 24, ano 14, p. 210-229, jul/dez 2017. 
As redes sociais têm influenciado os hábitos de consumo, além de interferir no funcionamento dos negócios. Para Martins e Silveira (2012, p. 01), “[...] o fenômeno da internet tem provocado mudanças no comportamento da sociedade, tanto no que se refere à comunicação e convívio social quanto no que tange à mudança no comportamento de consumo". Portanto, as redes sociais influenciam as ações do mercado na satisfação de desejos e de necessidades.

$\mathrm{Na}$ relação entre organização e consumidor, a empresa deve se integrar ao cliente para o desenvolvimento de ambos. Essa interação parte, portanto, do interesse da primeira de conhecer as necessidades e os desejos do segundo. Em um contexto de grande concorrência e de preocupação com a fidelidade do cliente, conhecer aquilo que o cativa e o satisfaz é fundamental para assegurar a sua permanência na empresa. Barth (2004 citado por MARTINS; SILVEIRA, 2012) afirma que entender a forma como os consumidores utilizam as plataformas eletrônicas com o intuito de realizar transações comerciais é fundamental para o sucesso das estratégias de marketing.

As redes sociais são um instrumento de valorização da marca das organizações. Desse modo, expor e comercializar bens e serviços dentro dessa estrutura é fundamental tanto com o propósito de injetar recursos no empreendimento, bem como de mantê-lo.

As ferramentas de comunicação visam explorar a marca da empresa, como marketing ambiental e esportivo, responsabilidade social etc. Assim, tendo em vista que o custo dessas mídias é elevado, as redes são uma alternativa para as organizações explorarem e fortalecerem as respectivas marcas. Segundo Alméri e colaboradores (2013, p. 2),

As redes sociais digitais entram em cena para formar grupos de interação pessoal e troca de informação rápida, troca de interesses comuns. As organizações utilizam essas redes digitais como ferramenta de marketing para divulgar um produto, uma marca, uma imagem ou simplesmente estar mais próximo de seus clientes.

Desse modo, uma vez que o consumidor tem a chance de receber o bem ou serviço de forma satisfatória, a empresa evolui no que se refere à qualidade daquilo que oferta e contribui definitivamente para o processo de tomada de decisão de escolher algo que supra uma necessidade e/ou um desejo. Em suma, as informações são importantes tanto para o consumidor quanto para o produtor de bens e serviços.

Silva (2010 p. 3) assegura que "[...] a informação e a comunicação empregadas como estratégias empresariais se tornam um recurso que tem o poder de transformar a posição da empresa para seus clientes e para a sociedade em geral". Juntas, informação e comunicação constituem ferramentas de

Página 214 Caderno de Ciências Sociais Aplicadas, Vitória da Conquista/BA, vol. 14, n 24, ano 14, p. 210-229, jul/dez 2017. 
estratégia empresarial para atingir o sucesso, captar clientes e transformar continuamente os modelos de comunidade. Silva (2010) declara ainda que reconhecer a comunicação como estratégia empresarial contribui para fechar bons negócios e ampliar relacionamentos. Raslan (2009, p.13) adverte: “[...] essa comunicação pode ser eficaz ou não, daí a importância de um programa bem elaborado que busque atingir as metas propostas por cada organização”. Desse contexto, é possível compreender a importância da participação dos influenciadores digitais na sociedade de consumo.

É notório, pois, que a publicidade influencia a cultura e também o modo como os indivíduos enxergam o mundo. Assim, o consumidor adquire o produto que julga ser vantajoso e tal aquisição, muitas vezes, contribui para a criação de "modos de viver". Na opinião de Beleli (2007, p.193), “[...] a propaganda é um meio divulgador de cultura". A publicidade e a propaganda recorrem, portanto, a informações que demonstrem o desejo e a necessidade do consumidor. Segundo Carvalho (1996, p.13), “[...] toda a estrutura publicitária sustenta uma argumentação icônico-linguística que leva o consumidor a convencer-se consciente ou inconscientemente”. Para esse autor, “[...] a publicidade impõe, nas linhas e entrelinhas, valores, mitos, ideais e outras elaborações simbólicas, utilizando os recursos próprios da língua que lhe serve de veículo" (CARVALHO, 1996, p.13). Por certo, a publicidade e a propaganda influenciam o consumidor e determinam de que modo a sociedade se comporta e interage com o mundo.

\section{Procedimentos metodológicos}

A presente pesquisa é de natureza teórico-empírica. Com base em uma revisão de literatura, seu objetivo é discutir e compreender o tema em questão. De acordo com Fantinato (2015, p. 5), a pesquisa teórica "[...] é dedicada a (re)construir teoria, conceitos, ideias, ideologias, polêmicas, tendo em vista, em termos imediatos, aprimorar fundamentos teóricos”. O autor afirma que a pesquisa empírica baseia-se na “[...] na experiência comum e na observação; um fato que se apoia somente em experiências vividas, na observação de coisas, e não em teorias" (FANTINATO, 2015, p. 6).

Quanto ao tipo, o estudo é exploratório e descritivo. Marconi e Lakatos (2002, p.20) dizem que os estudos exploratórios “[...] enfatizam a descoberta de ideias e discernimentos". Ademais, o estudo exploratório tem como objetivo a formulação de hipóteses e questões. Os estudos descritivos “[...] descrevem um fenômeno ou situação, mediante um estudo realizado em determinado espaço-tempo".

A estratégia de pesquisa utilizada foi o estudo de caso. No ponto de vista de Cezana, Oliveira e Cotta (2011, p.3), “[...] o estudo de caso é uma categoria especial de pesquisa na qual são utilizados

Página 215 Caderno de Ciências Sociais Aplicadas, Vitória da Conquista/BA, vol. 14, n 24, ano 14, p. 210-229, jul/dez 2017. 
poucos ou apenas um objeto de estudo, que são analisados a exaustão, buscando-se explorar todas as variáveis presentes". Debruçar-se sobre o tema influenciadoras digitais e seu papel no mercado de Vitória da Conquista significa analisar as diversas indagações sobre o assunto. Yin (2001, p. 23) aponta três condições principais do estudo de caso como método de pesquisa: a natureza exploratória do estudo, a falta de controle do pesquisador sobre as variáveis envolvidas no evento em questão e o foco em acontecimentos contemporâneos.

A presente pesquisa foi realizada em Vitória da Conquista, na Bahia, com dezesseis influenciadoras. Conforme Marconi e Lakatos (2002), amostra é uma parte escolhida de um universo (população) e também um subconjunto do universo. Além disso, uma vez que não foi possível delimitar a população do estudo, a opção foi pela amostragem não probabilística e pelo critério de acessibilidade. Conforme Massukado-Nakatani (2009), uma amostragem é não probabilística "quando é desconhecida a probabilidade de parte ou de toda a população". Tal critério se define como o menos rigoroso, pois ocorre mediante a seleção dos elementos a que se tem acesso para viabilizar a pesquisa (MASSUKADO-NAKATANI, 2009).

Serviram de instrumentos de coleta de dados o questionário e a entrevista. Na opinião de Fantinato (2015, p. 39), “[...] questionário é um instrumento de coleta de dados constituído por uma série ordenada de perguntas que devem ser respondidas por escritório pelo informante, sem a presença do pesquisador". Marconi e Lakatos (2002, p.92) mencionam que "[...] a entrevista é um encontro entre duas pessoas, a fim de que uma delas obtenha informações a respeito de um determinado assunto, mediante uma conversação de natureza profissional". O questionário foi aplicado, por acessibilidade, entre dezesseis influenciadoras, encontradas mediante pesquisa nas redes sociais. Desse grupo, cinco se dispuseram a participar da entrevista, fato que enriqueceu a interpretação dos dados empíricos.

A pesquisa adotou o tratamento quali-quantitativo. Kirschibaun (2013, p.180) ressalta que "Pesquisas quali são tradicionalmente associadas a interesses de pesquisa tipicamente subjetivistas". As pesquisas quanti geralmente respondem às exigências do paradigma "positivista". Os dados obtidos com o questionário receberam, portanto, tratamento estatístico e descritivo. As informações coletadas por meio das entrevistas foram gravadas, transcritas e tiveram seu conteúdo analisado à luz do referencial teórico e com base nos dados quantitativos.

Página 216 Caderno de Ciências Sociais Aplicadas, Vitória da Conquista/BA, vol. 14, n 24, ano 14, p. 210-229, jul/dez 2017. 


\section{Influenciadoras digitais: um estudo em Vitória da Conquista}

Mediante a aplicação do questionário e da entrevista, foi possível traçar o perfil das dezesseis respondentes e verificar os motivos que as levaram a ingressar nesse mercado. Todas são do sexo feminino, 56,25\% são solteiras e 50\% têm entre 21 e 25 anos. Boa parte delas recebe entre 1 e 2 salários mínimos (cerca de 43,80\%). Tal valor corresponde, na maioria das vezes, à atividade de influenciadora digital mais uma fonte secundária. Do total de informantes, $68,8 \%$ declararam ter outra renda.

A entrevistada 4, uma das que possuem outra receita, explica: "Eu não tenho um sonho de virar uma mega blogueira. Eu faço esse trabalho porque eu gosto muito. Eu faço o blog por amor. Hoje, o retorno financeiro que eu tenho com ele é mínimo, porque não é minha atividade principal." A entrevistada 1, que também conta com mais uma renda, acrescenta: "Meu objetivo é ser conhecida a nível Conquista. A internet hoje é muito volátil e por isso, não quero fazer dela minha única fonte de renda. Quero continuar com outras atividades, como a que eu estou fazendo agora, que é trabalhar com marketing digital".

O depoimento da entrevistada 5 confirma o que disseram as entrevistadas 1 e 4: "Faz um ano que estou muito focada com o blog e consigo tirar um bom dinheiro com o blog, mas não é sustento. Se eu fosse usar o blog como sustento, não serviria. Eu tenho outras fontes [de renda]”.

Tanto no questionário quanto na entrevista é possível obter informações a respeito das atividades das formadoras de opinião. Segundo uma das respondentes, a apresentação de um produto envolve inúmeras tarefas.

Quando recebo um produto para divulgar, pesquiso a respeito da marca e do produto, faço uso para obter opinião própria, penso nas fotos, na edição dessas fotos e no cenário dessas para divulgação, e acompanho os reflexos mediante meus seguidores, através da visualização de mensagens e respostas por meio de ferramentas, como email e direct (ENTREVISTADA 1).

A entrevistada 2, que também faz uso de outras ferramentas, além do Instagram, comenta:

Primeiro, Instagram que é um trabalho diário, e aí depois, tenho dois canais no YouTube. Vídeo já é muito complicado, porque tem que ter toda uma preparação de gravar, de edição, de pensar no conteúdo, elaborar e tudo mais. Depois disso, ainda posto no blog que aí já é um trabalho semanal (ENTREVISTADA 2).

Durante a entrevista, a blogueira tratou do principal instrumento de suas atividades. Segundo ela, “o Instagram é a fonte principal hoje em dia” (ENTREVISTADA 2). A entrevistada 5 declara: “O

Página 217 Caderno de Ciências Sociais Aplicadas, Vitória da Conquista/BA, vol. 14, nº 24, ano 14, p. 210-229, jul/dez 2017. 
patamar superior de divulgação hoje é o Instagram, porém, as empresas de fora de Conquista me veem mais através do blog, e entram em contado comigo através do e-mail”. E especifica as atividades desenvolvidas em seu blog, todas relacionadas à beleza:

Meu trabalho envolve fotografia e edição profissional, envolve pesquisa, não é apenas receber um produto e dizer que um produto vai hidratar seu cabelo porque tem isso ou aquilo. Quando eu vou jogar no blog, eu faço toda uma pesquisa. Responder email, responder todos os seguidores, faço teste de tudo que eu recebo.

Dos 16 questionários, 13 apontam o Instagram como a principal ferramenta de comunicação, seguido do Whatsapp. Em entrevista, uma das respondentes afirma:

Trabalho com um blog literário e o blog de beleza. São dois nichos de mercado diferentes. O meu público do blog de beleza é mais evidente no Instagram. A maioria das parcerias fechadas são principalmente por meio de direct, WhatAspp e indicações de outras amigas blogueiras (ENTREVISTADA 3).

A entrevistada 4 enfatiza a necessidade de as blogueiras acompanharem a tendência do leitor em relação às redes sociais:

A tendência das pessoas hoje é de lerem menos. No próprio Instagram não adianta colocar legendas grandes. Eu tenho que acompanhar o que é tendência para eu conseguir me destacar. Eu tenho sentido essa tendência de que as pessoas interessam mais pelo que assistem e veem. Por isso, quero me dedicar ao meu canal do YouTube (ENTREVISTADA 4).

De acordo com os depoimentos, as entrevistadas exercem atividades que demandam novas habilidades. Lenzi (2009) considera que o empreendedor desenvolve a economia, a sociedade e transforma o comportamento. A análise dos dados coletados em campo revela aproximação do ofício das empreendedoras com a discussão teórica sobre o perfil empreendedor. Restringir esses dois grupos a cumpridores de trabalhos constitui uma tarefa impossível. O que ambos almejam é transformar o meio em que vivem, com base em um posicionamento de destaque, especialmente considerando as habilidades e o tempo necessários para manter um canal de comunicação interativo e que demanda conhecimento técnico. 


\section{Empresas, produtos e serviços nas redes sociais: o apoio das influenciadoras digitais}

De acordo com as entrevistas, a apresentação de produtos e serviços nas redes sociais é de grande relevância para influenciadoras digitais, seguidores (público-alvo) e empresas. Para as primeiras, o retorno é financeiro ou por meio de permuta de produtos com as empresas. Os seguidores têm informações detalhadas acerca do bem ou serviço desejado. As empresas obtêm vantagem competitiva ao vincularem a sua marca às influenciadoras, as quais exercem o poder de persuasão. Bem gerenciadas, tais características resultam no aumento das vendas. Segundo Tomáel, Alcará e Dichiara (2005), as redes sociais transcendem o espaço físico e as suas relações refletem e influenciam a realidade. $\mathrm{Na}$ opinião de Morgado (2003 citado por MARTINS; SILVEIRA, 2012), além de expor os produtos, as empresas coletam informações para e sobre os seus clientes no espaço virtual.

Uma das entrevistadas declara que "[...] o marketing evoluiu muito e as pessoas passam a estar cada vez mais ligadas aos produtos divulgados" (ENTREVISTADA 1). Portanto, a relação entre consumidor e empresa deixou de ser apenas a troca de um valor por um bem ou serviço. Explorar a imagem de uma influenciadora digital passa a ser, portanto, de grande valia, uma vez que as empresas valem-se da proximidade desse profissional com o público e estreitam a ligação das suas marcas com os consumidores.

Os dados coletados estão de acordo com a discussão levantada por Almeida e colaboradores (2016), segundo os quais, a estratégia para disseminar uma mensagem amplia exponencialmente sua influência. Tomáel, Alcará e Di Chiara (2005) ressaltam que o compartilhamento da informação e do conhecimento é determinado pela inserção em rede e que essa ação constitui uma estratégia de usuários integrantes. Conforme Almeida e colaboradores (2016), as redes sociais exercem um grande poder na divulgação de produtos e serviços, com um custo menor, comparado ao de outras ferramentas de comunicação. Conforme a entrevistada 2:

Os resultados para a empresa que investe em meu trabalho, muitas vezes são até maiores que os meus como divulgadora do produto que eles oferecem. Os retornos financeiros para eles são bem maiores que o investimento que fizeram no meu trabalho.

A respondente afirmou, além disso: “[...] hoje a empresa precisa está mais próxima do cliente e nós blogueiras muitas vezes somos a ponte entre a empresa e o cliente” (ENTREVISTADA 2). Essa

Página 219 Caderno de Ciências Sociais Aplicadas, Vitória da Conquista/BA, vol. 14, n 24, ano 14, p. 210-229, jul/dez 2017. 
declaração confirma, por conseguinte, a importância do relacionamento da empresa com o potencial consumidor e das tecnologias em facilitar tais relações.

Martins e Silveira (2012) dizem que o comportamento da sociedade mudou devido à internet. Posto isso, é de suma importância verificar o que deve ser divulgado e quais produtos e serviços são mais sensíveis ao uso da rede. Antes, é necessário traçar o perfil dos seguidores.

Das dezesseis respondentes, quatorze declararam que seu público-alvo é constituído predominantemente por mulheres jovens residentes em Vitória da Conquista. De acordo com a entrevistada 1:

\begin{abstract}
Aqui no Instragram a gente tem como ver né? A gente tem uma ferramenta que dá pra você analisar todas as informações. É uma ferramenta que você mesma coloca. Você tem que ter uma Fanpage no Facebook e conectar essa página ao seu Instagram. É como se você transformasse a sua conta do Instagram numa conta de perfil profissional. Aí eu vejo que tenho 11538 seguidores. Aí eu posso ver que $69 \%$ são mulheres. A faixa etária principal é 18 a 24 anos e a faixa secundária é de 25 a 34 anos. A principal localização é Vitória da Conquista.
\end{abstract}

Ao que parece, o perfil traçado pela entrevistada 3 é semelhante ao descrito anteriormente: “O meu público é mais feminino e de jovens de 18 a 28 anos". A entrevistada 2 relata: “Tenho um público de 19 a 25 anos e são mais mulheres de maioria conquistense". A informante 4 afirma: "São 9.400 seguidores, a maioria mulher, entre 18 e e 34 anos. A maior parte é de 25 a 34 anos". E continua "55\% é mulher e a faixa etária é entre 18 a 24 e de 25 a 34 anos. Tenho 12.317 seguidores e é mais público jovem de Conquista".

Segundo os questionários e as entrevistas, os líderes do ramo são os dermocosméticos e os itens de moda. "As empresas me procuram principalmente para divulgar produtos de moda e beleza, que são limpeza de pele, cosméticos capilares e maquiagem" (ENTREVISTADA 2). A entrevistada 1 ratifica:

Eu sou muito procurada tanto por seguidoras quanto por empresas sobre o meu cabelo. Recebo muitos produtos de cabelo. Eu também iniciei falando muito de moda e desde o começo eu sou procurada para isso. Também falo muito de maquiagem. Fiquei super feliz quando ainda era pouco conhecida, mas uma empresa de maquiagem me procurou e confiou no meu trabalho e nos efeitos que ele traria.

A entrevistada 3 complementa: "Recebo muitos serviços. Por exemplo: minhas unhas, novos cortes de cabelo, sobrancelhas, enfim, muito mais na área de beleza e imagem pessoal mesmo". Segundo as informantes, existem outras áreas de investimento, mas, conforme demonstram as

Página 220 Caderno de Ciências Sociais Aplicadas, Vitória da Conquista/BA, vol. 14, n 24, ano 14, p. 210-229, jul/dez 2017. 


\section{- Cadernos de Ciências SOCIAIS APLICADAS}

respostas, os aspectos considerados mais importantes concentram-se no tópico beleza, evidenciado no ícone "outros".

Ao apontar as vias de maior investimento, uma entrevistada revela: "As empresas me procuram muito para divulgar produtos de cabelo, hoje represento uma empresa de cosméticos para cabelos lá do Rio de Janeiro e eles só trabalham com blogueiros" (ENTREVISTADA 3). Na opinião de outra respondente: "as empresas muitas vezes nos procuram para divulgarem justamente produtos que tem mais a ver com o que falamos" (ENTREVISTADA 2). Segundo a entrevistada 5: "Não é o que eu gostaria, mas as empresas me procuram para divulgar mais cosméticos e maquiagem. Eu gostaria que tivesse um foco um pouco mais diferente. Maternidade e arte, por exemplo. Eu gosto muito disso".

Conforme o questionário, na divulgação de produtos e serviços, moda e maquiagem gozam da preferência de $81 \%$ das participantes. O item cosmético foi destaque para 18\% delas. Os dados mostram, portanto, que empresas e blogueiras têm preferências distintas na divulgação de produtos e serviços. É o que demonstra o Gráfico 1.

Gráfico 1: Cruzamento - Vias de interesse: blogueiras x empresas

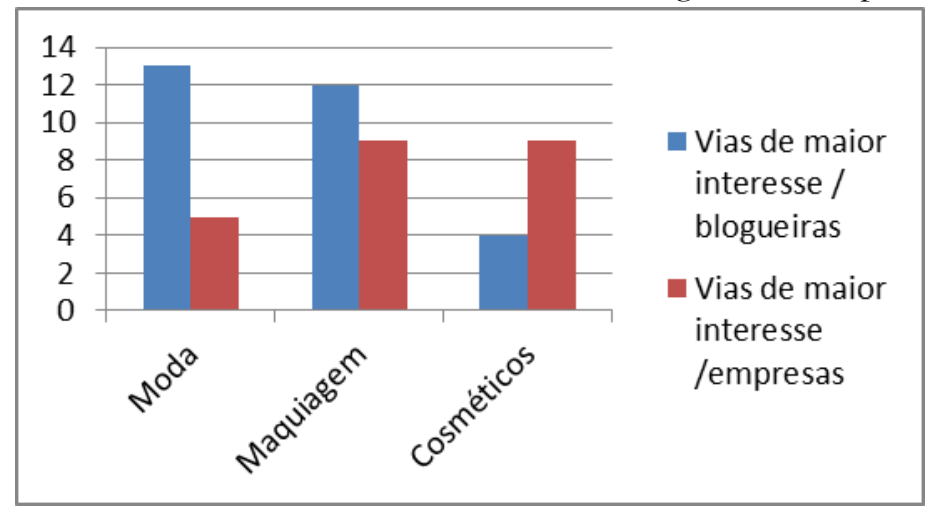

Fonte: Pesquisa de Campo (2017).

No quesito maquiagem, os interesses praticamente equiparam-se: entre as blogueiras, a preferência é de 75\%. Nove delas declararam que as empresas também têm predileção por esse item. Nos quesitos moda e cosméticos, os resultados divergem. O primeiro é a escolha de $81 \%$ das informantes e de $31 \%$ das empresas. Cosméticos é citado por apenas quatro das respondentes. Nove delas afirmaram que as empresas têm preferência por esse item. Talvez essa discrepância no tocante ao quesito "moda" se deve ao fato de existir uma grande quantidade de marcas, fato que pode ocasionar uma ausência de interesse em investir nesse canal. De forma diferente, os quesitos maquiagem e cosméticos ainda têm a marca como influenciadora na hora da compra.

Página 221 Caderno de Ciências Sociais Aplicadas, Vitória da Conquista/BA, vol. 14, nº 24, ano 14, p. 210-229, jul/dez 2017. 


\section{As influenciadoras digitais no mercado conquistense}

Conforme Drucker (2008), independentemente da motivação pessoal, o interesse dos empreendedores não é apenas melhorar o que já existe, mas desenvolver algo novo, diferente, para contribuir de alguma forma na criação de valor. A motivação das respondentes é influenciar pessoas: "Eu comecei porque minhas próprias amigas começaram a me pedir para postar dicas. Elas me viam como alguma referência de estilo. Antes mesmo de começar o blog eu já influenciava de uma certa forma" (ENTREVISTADA 1). Outras informantes sustentam a declaração anterior: "Tenho um grupo de amigos que me influenciou. Eu percebi que sabia de coisas que as outras pessoas não sabiam" (ENTREVISTADA 3).

Foi sem nenhuma pretensão. Comecei há quatro anos e percebi a resposta mesmo, tanto dos seguidores quanto das empresas, em três anos. Quem não quer ter um retorno de algo que gosta de fazer? (ENTREVISTADA 2).

As respostas dos questionários aproximam-se das entrevistas. Das dezesseis respondentes, 50\% revelaram que a principal motivação para esse trabalho é influenciar pessoas. Martins e Silveira (2012) declaram que o advento da internet interferiu no comportamento da sociedade e do consumidor. Com isso, a intenção das formadoras de opinião é inovar, ou seja, construir conhecimentos e influenciar pessoas mediante postagens e publicações.

Conhecer o potencial de influência das formadoras de opinião nas redes sociais e o tempo dedicado a essa ocupação é importante para entender os seus efeitos: "Tenho 11.538 seguidores" (ENTREVISTADA 1). “Tenho por volta de 11.200 seguidores em meu Instragram, que é voltado para beleza" (ENTREVISTADA 2). "Comecei em novembro do ano passado (2016) e já tenho cerca de 1.100 seguidores e algumas empresas já me procuram” (ENTREVISTADA 3).

De acordo com os questionários, $69 \%$ das influenciadoras contam com até vinte mil seguidores nas redes sociais, 38\% delas têm entre mil e dez mil e 31\% entre 10.001 e 20.000. Entre as entrevistadas, 13\% declararam que possuem mais de sessenta mil seguidores. Alméri e colaboradores (2013) afirmam que quanto mais o serviço dessas pessoas se expande, mais as empresas fazem uso desse canal.

Quando questionadas sobre o tempo dedicado à atividade, as formadoras de opinião afirmaram que dispensam a maior parte do dia para esse serviço. Das dezesseis entrevistadas, seis declararam que destinam às redes mais de sete horas diárias; três, de cinco a sete horas, e cinco, de três a cinco horas

Página 222 Caderno de Ciências Sociais Aplicadas, Vitória da Conquista/BA, vol. 14, nº 24, ano 14, p. 210-229, jul/dez 2017. 


\section{- Cadernos de CiêncIas SOCIAIS APLICADAS}

por dia. As informações das entrevistas harmonizam-se com as dos questionários: "É o tempo inteiro" (ENTREVISTADA 1). “O Instagram é um trabalho diário” (ENTREVISTADA 2).

Ao comparar o tempo destinado às redes sociais com o estado civil das participantes, verificou-se que $44,4 \%$ das que se declararam solteiras dedicam mais de sete horas a essa ocupação; entre as casadas, o percentual é menor, $42,9 \%$ reservam entre três e cinco horas diárias. Isso demonstra que as solteiras dispõem de mais tempo para apresentar produtos e serviços.

$\mathrm{Na}$ comparação entre estado civil e número médio de seguidores, o objetivo foi verificar se o tempo dedicado ao trabalho e o estado civil interferem no nível de influência entre os consumidores (Gráfico 2).

Gráfico 2: Estado Civil * Média de seguidores - Tabulação cruzada

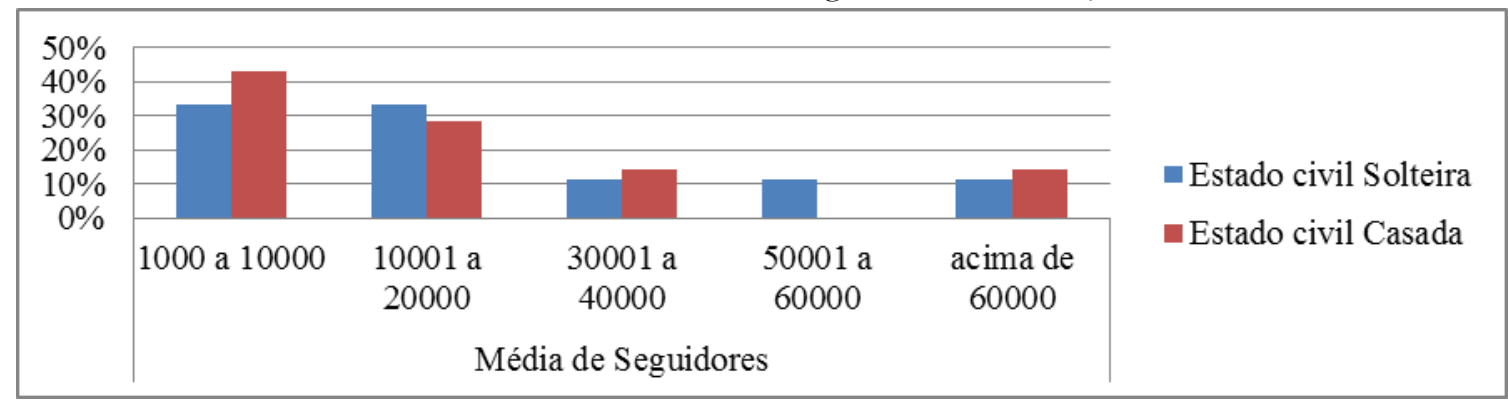

Fonte: Pesquisa de Campo (2017).

Os resultados no tocante à relação do estado civil das blogueiras com o tempo dedicado à tarefa e o número de seguidores, não chamam atenção. A diferença é inexpressiva, mas, com o passar do tempo pode aumentar. De qualquer modo, a maior concentração de seguidores está entre as informantes que se dedicam mais de sete horas diárias à atividade (Gráfico 3).

Página 223 Caderno de Ciências Sociais Aplicadas, Vitória da Conquista/BA, vol. 14, n 24, ano 14, p. 210-229, jul/dez 2017. 


\section{Cadernos de Ciências SOCIAIS APLICADAS}

Gráfico 3: Tempo médio nas redes soociais * Média de seguidores - tabulação cruzada.

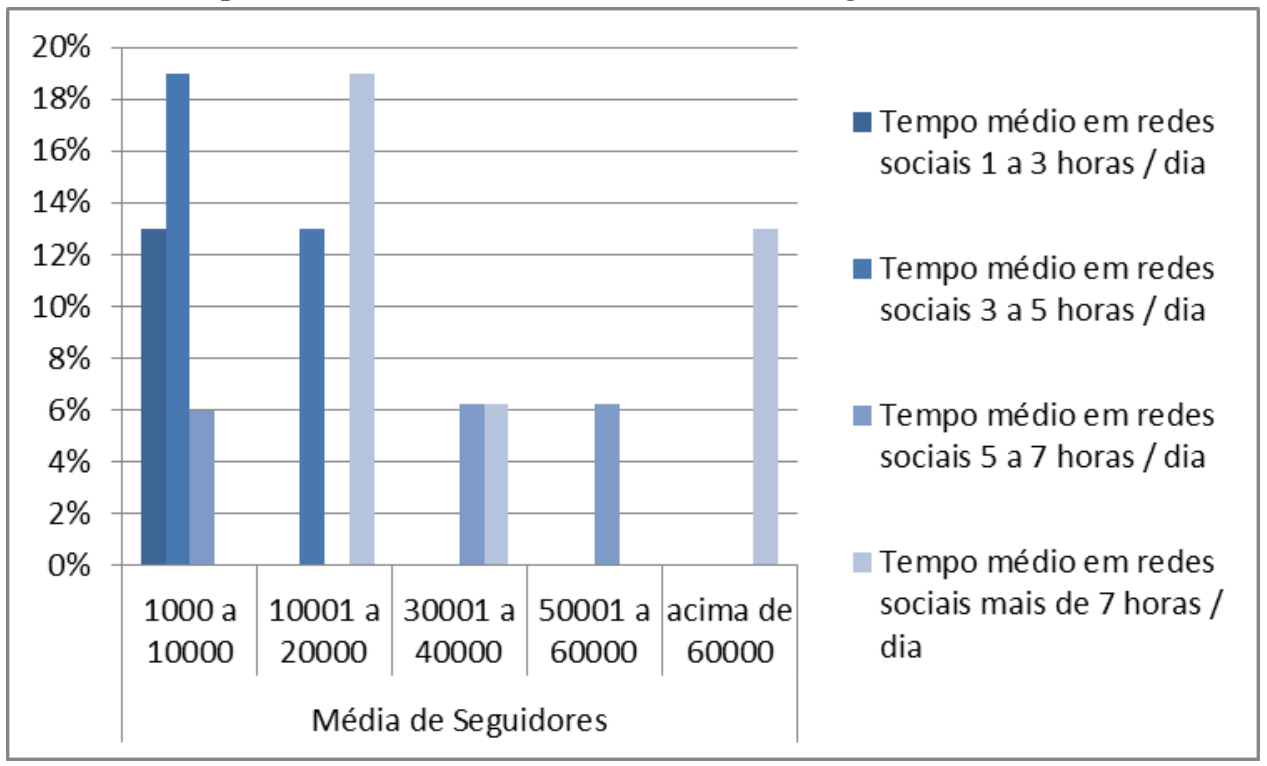

Fonte: Pesquisa de Campo (2017).

Entre as dezesseis entrevistadas, $37 \%$ se dedicam mais de sete horas ao trabalho. Desse percentual, $66 \%$ possuem mais de sessenta mil seguidores. Das 31\% que dedicam de três a cinco horas, 60\% estão com até dez mil seguidores e duas entre dez mil e um e vinte mil seguidores.

Conforme mostrou o resultado, quanto mais tempo nas redes sociais, maior a possibilidade de ampliação do número de seguidores e de qualificação para algumas empresas. Segundo Tomáel, Alcará e Di Chiara (2005), as redes se expandem conforme sua inserção nas relações comerciais. Na opinião de Silva (2010), estratégias como a informação e a comunicação interferem no posicionamento do públicoalvo e na economia. Os depoimentos confirmam a influência das blogueiras no mercado conquistense:

Pessoas me procuram a respeito do meu cabelo. Elas querem que eu indique produtos sobre esses tipos de cuidado. As empresas percebem isso vendo minhas publicações e me procuram para divulgar o produto e o serviço deles (ENTREVISTADA 1).

De acordo com outra informante:

Ainda tenho pouco seguidores, mais sou muito procurada para serviços. As empresas dão corte de cabelo, manicure, agora mesmo já vou em uma empresa que trabalha com design de sobrancelhas, vou fazer a minha, e em troca eu vou postar algo sobre o trabalho deles (ENTREVISTADA 3). 
A informante 2 demonstra admiração com os resultados do seu trabalho: "Até hoje eu me surpreendo na verdade. Há três anos já vejo que exerço uma influência tanto pelo blog literário, quanto pelo blog de beleza". A entrevistada 4 declara:

$\mathrm{Na}$ verdade, eu faço muita coisa de internet há muitos anos, desde que eu tinha uns 17, mas como muita coisa mudou de lá pra cá, em nem considero esse tempo todo como influencer, porque era época do Fotolog. Fotolog acabou. Então eu considero que de quatro anos pra cá, percebi os reflexos do meu trabalho como blogueira.

A entrevistada 5 complementa:

Quando eu comecei com o blog, jamais pensei que eu tinha o poder de influenciar pessoas. $\mathrm{Na}$ verdade, até hoje eu duvido. Eu tenho um perfil empreendedor, eu gosto de estar inovando e trazendo alguma coisa diferente, mas sempre com os pés no chão. Penso como um novo empreendedor que está entrando para dar a cara a tapa.

Julien (2010) confirma o depoimento anterior, ao considerar que o empreendedor deve conhecer os limites da sociedade em que vive. Os dados estão de acordo com as ponderações de Alméri e colaboradores (2013), segundo os quais existe uma interação pessoal e uma troca rápida de informações nas redes sociais digitais. Além disso, as organizações confiam a essas redes a função de divulgar um produto, uma marca, uma imagem ou, simplesmente, de se aproximar do público-alvo. Almeida e colaboradores (2016) ressaltam que a interação das pessoas com os conteúdos on-line produzidos pelas marcas e o marketing viral podem funcionar em conjunto. Isso é perceptível na presente pesquisa, uma vez que a troca de informações tem um potencial muito maior de disseminação nas redes sociais.

O trecho a seguir trata dessa conexão do público com as redes:

Hoje em dia, principalmente uma empresa de cosméticos, tem um público mais jovem, né? Essa também é faixa etária mais comum do público que está na internet. Então, é o meu público que está nas redes sociais. Então, é extremamente importante a divulgação (ENTREVISTADA 2).

Outra respondente chama atenção para os benefícios do mercado:

A vantagem é que o seguidor entre em blogs para ver o que as blogueiras falam a respeito do assunto de interesse, se tem vantagem, se é bonito, se não é, perguntam se realmente gostou, onde vende, quanto custa, enfim, eu sempre indico as empresas, e com isso, as empresas têm um crescimento de vendas (ENTREVISTADA 3).

Na opinião da entrevistada 1, “[...] o Marketing evoluiu muito e as pessoas passam a estar cada vez mais ligadas aos produtos divulgados". Segundo ela, as organizações devem manter um

Página 225 Caderno de Ciências Sociais Aplicadas, Vitória da Conquista/BA, vol. 14, n 24, ano 14, p. 210-229, jul/dez 2017. 
relacionamento mais próximo com o potencial consumidor, apresentando o bem ou serviço mais adequado às necessidades e aos desejos de cada um. Souza (2000) afirma que a venda de bens e serviços deve ser uma demonstração de modelos a serem seguidos e o objetivo mais evidente na publicidade é demonstrar as vantagens de cada produto. Conforme a informante 1:

As empresas precisam se achegar e se adequar. As influenciadoras digitais são o meio principal de divulgação, porque é o que está mais próximo do público. A palavra fundamental é o relacionamento. Hoje em dia o marketing está baseado no relacionamento entre as pessoas e as redes sociais também são baseadas em relacionamentos (ENTREVISTADA 1).

Apoiado em uma ideia mais antiga, mas de uma maneira bastante atual, Carvalho (1996) afirma que a publicidade leva o consumidor a convencer-se consciente e inconscientemente. A respeito das vantagens para as empresas e para as leitoras, a entrevistada 5 opina:

Se você tem uma loja bacana ou tem um produto legal e de excelente qualidade. As empresas sabem que o que importa hoje em dia é a divulgação na internet. Então, a importância seria essa porque todo mundo hoje em dia reconhece que uma blogueira de fato, tem muita importância na vendagem dos produtos. A primeira coisa que aumenta é a visibilidade.(...) Minha preocupação é passar credibilidade para as pessoas e as empresas conseguirem vender com a minha propaganda (ENTREVISTADA 5).

As entrevistadas 2 e 4 afirmam que o impacto em empreendimentos menores é bastante expressivo: "Algumas empresas menores de comida, por exemplo, me procuram e eu fico muito feliz quando elas têm um retorno positivo" (ENTREVISTADA 2). "As empresas de pequeno porte são muito agradecidas, pois elas ganham visibilidade" (ENTREVISTADA 4).

Algumas informantes evidenciaram certa preocupação com a maneira como devem postar qualquer assunto, pois acreditam que a atitude também influencia outras pessoas: "Me preocupo muito em não passar uma mensagem de consumo desenfreado". A entrevistada 1 destaca a importância do cuidado com a mensagem: "Prezo muito por essa questão de passar valores importantes para as pessoas. Eu sempre tenho muito cuidado com as coisas que eu vou falar nas redes sociais, eu sempre pretendo (...) prezar pelo amor, pela ajuda ao próximo” (ENTREVISTADA 1).

Em suma, os efeitos do trabalho das influenciadoras digitais no mercado de Vitória da Conquista são evidentes. As empresas podem manter relacionamentos com os clientes e influenciá-los na hora da decisão de comprar, além de crescer em visibilidade e obter mais informações sobre as necessidades e desejos do público-alvo. Essas informações estão de acordo com Silva (2010), segundo o qual a comunicação auxilia no fechamento de bons negócios e na ampliação de relacionamentos, quando 
utilizada como estratégia empresarial. No entendimento de Souza (2000), a publicidade divulga modelos e seu principal objetivo é mostrar as vantagens dos produtos. Vê-se, por conseguinte, que o referencial teórico embasa as ideias expressas nas respostas aos questionários e nas entrevistas, a respeito da importância e do papel desempenhado por formadoras de opinião no mercado de Vitória da Conquista.

\section{Considerações finais}

O que motivou esta pesquisa foram as diferentes formas de empreender e as novas configurações do mercado, as quais se destacam pela inovação e modernidade. Discutir sobre empreendedorismo, inovação e ferramentas de comunicação nas redes sociais passou a ser imprescindível neste artigo. Ao compreender essa nova atividade, identificou-se o gradativo crescimento no número de pessoas que exercem influência nas redes e contribuem para a formação de opinião de seus seguidores. Nesse contexto, organizações passaram a considerá-las dotadas de poder para influenciar outras no consumo de bens e serviços.

Sobre a importância da apresentação de produtos por meio das redes sociais, verifica-se que as influenciadoras exercem influência sobre seus seguidores e essa modalidade de divulgação é essencial para o alcance de objetivos. Na percepção das entrevistadas e conforme demonstram os resultados da pesquisa, com esse investimento, as empresas têm um retorno positivo, visto que se aproximam do seu público-alvo, os potenciais consumidores. Isso faz com que as organizações também conheçam, mediante as influenciadoras, um pouco mais dos desejos e necessidades dos considerados clientes.

Com retorno garantido na divulgação de bens e serviços por meio das redes sociais, as organizações concentram-se nas vias que apresentam mais necessidade de investimento. Neste estudo, identificou-se a relevância dos produtos e serviços do universo da beleza, especialmente maquiagem, moda e cosméticos.

As organizações identificam a importância da divulgação e as formadoras de opinião passam a ser reconhecidas por seguidores e também pelas empresas, haja vista os investimentos crescentes nessa modalidade de serviço. Conforme apontam os resultados, ao fornecer para o consumidor informações sobre o bem ou serviço que ele pretende adquirir, tal atividade fomenta o crescimento de pequenos empreendimentos. O aumento no número de seguidores é evidente em Vitória da Conquista.

A pesquisa de campo revelou que os seguidores adquirem produtos e serviços com base na opinião das influenciadoras e que algumas superam a marca dos 50.000 seguidores. A maioria das blogueiras considera essa atividade muito importante.

Página 227 Caderno de Ciências Sociais Aplicadas, Vitória da Conquista/BA, vol. 14, n 24, ano 14, p. 210-229, jul/dez 2017. 
Aos poucos, as empresas reconhecem no trabalho dos influenciadores digitais uma forma de investir, de adquirir visibilidade e de crescer. É imprescindível que haja mais estudos voltados a esse ramo, pois eles serão a base para estudos futuros. Por tratar de um tema inovador, esta pesquisa deve ser levada adiante. Uma proposta a ser considerada é analisar a percepção dos empresários sobre tal estratégia mercadológica.

\section{Referências}

ALMEIDA, M. I. S. A. et al. "Engaja-me e atraia-me, então eu compartilharei": uma análise do impacto da categoria da postagem no marketing viral em uma rede social. RBGN - Revista Brasileira de Gestão e Negócios, São Paulo, v. 18, n. 62, p. 545-569, out./dez. 2016.

ALMERI, T. M. et al. A influencia das redes sociais nas organizações. Revista de Administração da FATEA - RAF, Teresa D’Ávila, v.7, n. 7, p.132-146, ago./dez. 2013.

BELELI, I. Corpo e Identidade na Propaganda. São Paulo: UNICAMP, 2007.

CARVAlHO, N. Publicidade: a linguagem da sedução. São Paulo: Ática, 1996.

CEZANA, D. P; OliveirA, O. M; COTTA, T. R. Pesquisa do Tipo Levantamento versus Pesquisa do Tipo estudo de Caso. Jerônimo Monteira, ES: UFES, 2011.

DRUCKER, P. F. Inovação e empreendedorismo: Práticas e princípios. São Paulo SP: Cencage Learning, 2008.

FANTINATO, M. Métodos da Pesquisa. São Paulo: USP, 2015.

FILION, L. J. Empreendedorismo e Gerenciamento: processos distintos, porém complementares. Revista de Administração de Empresas ERA, São Paulo, v.7, n.3, p. 2-7 jul./set. 1999.

JULIEN, P. A. Empreendedorismo Regional e economia do conhecimento. 1. ed. São Paulo: Saraiva, 2010.

LAKATOS, E.M.; MARCONI, M. de A. Técnicas de pesquisa. 5. ed. São Paulo: Atlas, 2002.

LENZI, F. A Nova Geração de Empreendedores: Guia para a elaboração de um plano de negócios. 1. ed. São Paulo. Atlas, 2009.

MARTINS, A. C. C.; SILVEIRA, J. V. A Influência das Redes Sociais no Comportamento do Consumidor Online. In: CONGRESSO NACIONAL EM EXCELÊNCIA EM GESTÃO, 8., 2012, Rio de Janeiro. Anais... Rio de Janeiro: UFF, 2012.

MASSUKADO-NAKATANI, M. S. Métodos e técnicas de pesquisa em turismo: Amostragem. 2009. Disponível em: <http://www.turismo.ufpr.br/drupal5/files/ Aula\%2022\%20\%20Amostragem.pdf $>$. Acesso em: 10 de abril 2017.

Página 228 Caderno de Ciências Sociais Aplicadas, Vitória da Conquista/BA, vol. 14, n 24, ano 14, p. 210-229, jul/dez 2017. 
RASLAN, E. M. S. Análise de Efetividade da Comunicação Estratégica em Instituições: Um estudo da Arquidiocese de Belo Horizonte. 2009. 143 f. Dissertação (Mestrado em administração), Universidade FUMEC, Belo Horizonte, 2009.

SILVA, R. C. Informação e Comunicação em Ambientes Organizacionais: estratégias para uma gestão eficiente. Revista eletrônica de comunicação, Franca-SP, v. 5, n. 1, 2010.

SOUZA, L. C. C. F. Educação e Publicidade. São Paulo: PUC SP, 2000.

SHUMPETER, J. A teoria do desenvolvimento Econômico: uma investigação sobre lucros, capital crédito, juros e o ciclo econômico. 2. ed. São Paulo: Nova Cultural, 1985.

TOMÁEL, M. I; ALCARÁ, A. R; DI CHIARA, I. G. Das Redes Sociais à Inovação. Ci. Inf, Brasília, v34, n.2, p.93-104, maio/ago. 2005.

YIN, R. K. Estudo de caso: planejamento e métodos. 2. ed. Porto Alegre: Bookman, 2001. 